\title{
Gender differences and tuberculosis in the Syrian Arab Republic: patients' attitudes, compliance and outcomes
}

H. Bashour ${ }^{1}$ and F. Mamaree ${ }^{2}$

$$
\begin{aligned}
& \text { الاختلافات بين الجنسين في ما يتعلق بمرض السل في الجمههورية العربية السورية: مواقف المرضى المقلى }
\end{aligned}
$$

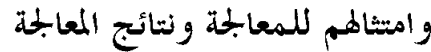

$$
\begin{aligned}
& \text { هيام بشور، فاديا معماري }
\end{aligned}
$$

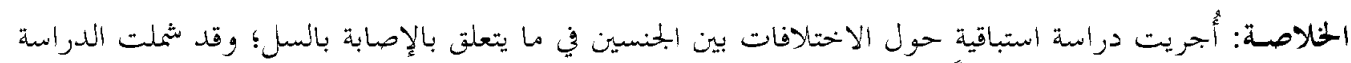

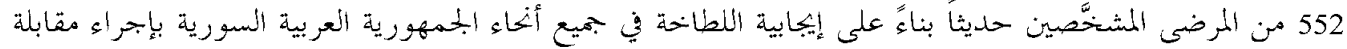

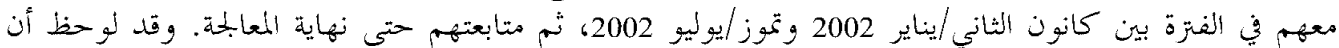

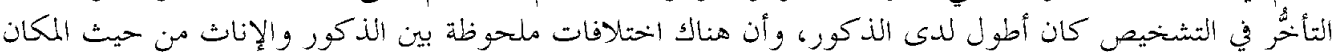

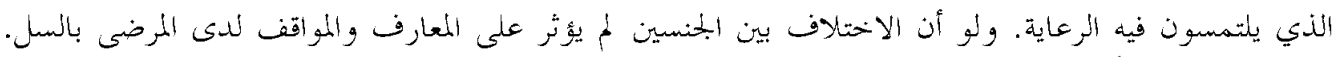

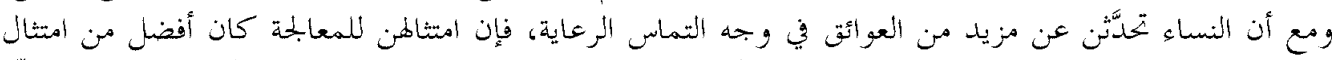

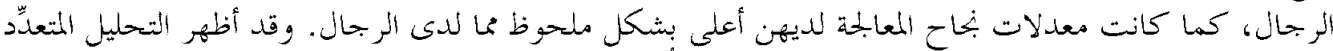

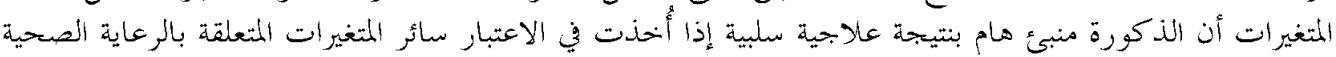

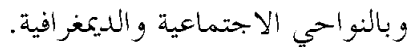

ABSTRACT In a prospective study of gender and TB outcomes, 552 newly diagnosed smear-positive patients throughout the Syrian Arab Republic were interviewed at recruitment (from January 2002 to July 2002) and followed until the end of treatment. Delay in diagnosis was significantly longer among males. Significant differences between males and females were noted in relation to the place they usually use to seek care. Gender did not seem to affect knowledge and attitudes of TB patients. Although the women reported more barriers to seeking care, compliance with treatment tended to be higher and the treatment success rate was significantly higher among females than males. Multivariate analysis showed that male sex was a significant predictor of a negative treatment outcome, after controlling for other significant sociodemographic and health care related variables.

\begin{abstract}
Sexospécificités et tuberculose en République arabe syrienne : attitudes des patients, observance et issue du traitement

RESUME Dans une étude prospective des sexospécificités et de l'issue du traitement de la tuberculose, 552 patients frottis positif récemment diagnostiqués dans la République arabe syrienne ont été interrogés à leur recrutement (entre janvier 2002 et juillet 2002) et suivis jusqu'à la fin du traitement. Le retard dans le diagnostic était nettement plus important chez les hommes. Des différences significatives entre les hommes et les femmes ont été notées en ce qui concerne l'endroit où ils s'adressent généralement pour bénéficier de soins. Le sexe ne semblait pas influer sur les connaissances et les attitudes des patients tuberculeux. Bien que les femmes aient signalé davantage d'obstacles pour se faire soigner, l'observance du traitement avait tendance à être meilleure et le taux de réussite du traitement était significativement plus élevé chez les femmes que chez les hommes. Une analyse multivariée a révélé que le sexe masculin était un facteur prédictif important d'une issue négative du traitement, après le contrôle d'autres variables importantes sociodémographiques et liées aux soins de santé.
\end{abstract}

${ }^{1}$ Department of Community Medicine, Faculty of Medicine, University of Damascus, Damascus, Syrian Arab Republic.

${ }^{2}$ National Programme of Tuberculosis, Ministry of Health, Damascus, Syrian Arab Republic.

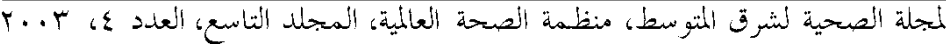




\section{Introduction}

Gender inequality has long been identified as a major determinant that can lead to delay in diagnosis, poor access to health care, lack of compliance and also poor treatment outcomes. Health care seeking and treatment behaviour of men and women suffering from tuberculosis (TB) is largely determined by how they and those around them perceive the symptoms, regard the diagnosis, accept the treatment, and adhere with it. Thus, gender may well influence the detection of the disease and its outcome [1]. Many studies have been conducted in different parts of the world in connection with gender differences in TB [2-8]. These report that, when they seek health care, women are not diagnosed with TB by doctors or other health care providers as often men. They also report that sputum submission rates are different between men and women. However, women are seen as more compliant to treatment than men.

Globally, TB occurs more often in men than in women $[1,9]$. In most countries with available data, the female to male ratio among prevalent TB cases identified in population surveys is similar to that among notified cases [6]. In the Syrian Arab Republic, the case notification rate suggests that TB may be less frequent among females [10]. In 2001, the ratio of female to male smear-positive TB cases was 1:1.8 [11]. There is no previous research in our country that examined gender-related differences in diagnosis, compliance and treatment outcomes of TB. We thus conducted this study with the following objectives:

- to determine whether there are sex differences in diagnosis, compliance with treatment and/or treatment outcomes of TB patients;
- to identify TB patients' (both men and women) knowledge, beliefs and attitudes towards TB;

- to identify gender-related factors and/or barriers that may influence patients' compliance with TB treatment and utilization of health care services.

\section{Methods}

\section{Subjects}

This prospective study recruited a total of 552 new smear-positive TB patients seen at all provincial TB centres (14 centres) in the Syrian Arab Republic during the period 2 January 2002 to 31 July 2002. The recruitment occurred when a new smear-positive case of TB was diagnosed. The cohort of patients was followed-up for 6 months until the end of their treatment period.

\section{Data collection}

At recruitment, patients were interviewed using a semi-structured questionnaire. The questionnaire was field tested before the study, and necessary changes were made accordingly. The final questionnaire consisted of 70 items; both close-ended and open-ended. The data collected included: background information; detailed clinical information including signs and symptoms and start date; care-seeking behaviour and information on the patient's contacts. Patients were asked about their TB-related knowledge including the mode of transmission and stigma of the disease. Patients' perceptions of gender differences in TB diagnosis and care-seeking behaviour were studied. Data on utilization of health services and patients' satisfaction with the services were also obtained.

The questionnaires were administered by trained health personnel that included 
both doctors or paramedics working with the Syrian National Tuberculosis Programme. Fieldwork was supervised to improve the quality of data collection.

Patients' treatment cards were reviewed to collect data on compliance with treatment and examinations and treatment outcome. Compliance with drug treatment was defined as 0 days of missed treatment, i.e. 0/60 days in the initial phase (daily administration), and $0 / 120$ days in the continuation phase of treatment (weekly administration), as seen on the treatment cards.

Treatment outcomes were determined according to WHO definitions [10].

The informed consent of the patient was taken before the interview, and the study proposal was cleared by the relevant ethical review boards.

\section{Statistical analysis}

Data from questionnaires were checked before data entry. Missing values were allowed for in the analysis; thus, in some of the tables reported here, the total number of respondents differs from the study sample size. Descriptive statistics were used to examine the subjects' characteristics. For the comparison between sexes, the chisquared test was used to compare proportions, and the Student $t$-test was used to compare means. Summation scores for patients' knowledge, gender perceptions and satisfaction with care were calculated. The score was calculated after recoding answers as ' 1 ' for correct or positive, and ' 0 ' if incorrect or negative.

Treatment outcomes were compared between males and females. Treatment outcomes were then recoded as a dichotomous variable, including 'success of treatment' defined as cure or completed treatment; and 'no success' defined as default, failure or death. Transferred cases were excluded from this analysis. The relative risk (RR) and attributable fraction (RR-1/RR) for determinants of the treatment outcome were then calculated. Multivariate analysis was performed to determine the predictors of treatment outcome; thus adjusted relative risk (RR) and its $95 \%$ confidence intervals (CI) were calculated. Variables entered in the model for the multivariate analysis were those significant at the level of 0.1 in the bivariate analysis.

\section{Results}

\section{Follow-up status and background characteristics of study subjects}

Information was collected from 552 patients seen at TB centres out of a total of 800 new smear-positive patients registered in those centres during the recruitment period of the study. Those who were not recruited included those who refused, were hard to communicate with or who were not seen by the trained interviewers for different reasons. There were $366(66.3 \%)$ males and 186 (33.7\%) females. In order to avoid any selection bias, the female to male ratio for the study subjects and for those registered at TB centres were compared. That ratio was also presented by province. No difference was seen in the female to male ratio between registered (1:1.87) and recruited (1:1.97) TB patients.

Most of the study subjects were in the younger age groups: $14.9 \%$ were under 20 years and $44.9 \%$ aged $20-29$ years. Onefifth $(20.7 \%)$ of the patients had no formal education, while $11.8 \%$ had a higher level of education. The mean monthly household income was 6643.5 Syrian pounds (US\$ 1 $=53 \mathrm{SP}$ ). Table 1 compares the demographic and socioeconomic characteristics of the sexes; significant differences were

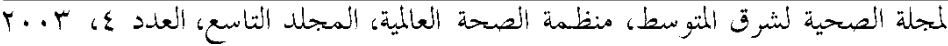




\begin{tabular}{|c|c|c|c|c|c|}
\hline \multirow[t]{2}{*}{ Variable } & \multicolumn{2}{|c|}{ Males $(n=366)$} & \multicolumn{2}{|c|}{ Females $(n=186)$} & \multirow[t]{2}{*}{$P$-value } \\
\hline & No. & $\%$ & No. & $\%$ & \\
\hline \multicolumn{6}{|l|}{ Age (years) } \\
\hline$<20$ & 42 & 11.5 & 40 & 21.5 & 0.002 \\
\hline $20-29$ & 167 & 45.6 & 81 & 43.5 & \\
\hline 30-39 & 71 & 19.4 & 19 & 10.2 & \\
\hline $40+$ & 86 & 23.5 & 46 & 24.7 & \\
\hline \multicolumn{6}{|l|}{ Marital status } \\
\hline Single & 181 & 49.6 & 78 & 42.2 & $<0.001$ \\
\hline Married & 180 & 49.3 & 94 & 50.8 & \\
\hline Other & 4 & 1.1 & 13 & 7.0 & \\
\hline \multicolumn{6}{|l|}{ Occupation } \\
\hline Unemployed & 41 & 11.6 & 122 & 77.7 & $<0.001$ \\
\hline Labourer & 107 & 30.4 & 4 & 2.5 & \\
\hline Agriculture & 49 & 13.9 & 10 & 6.4 & \\
\hline Military & 34 & 9.5 & 0 & 0 & \\
\hline Small business & 74 & 21.0 & 8 & 5.1 & \\
\hline Clerk & 34 & 9.7 & 1 & 0.6 & \\
\hline Other & 14 & 4.0 & 11 & 7.0 & \\
\hline \multicolumn{6}{|l|}{ Education (years) } \\
\hline None & 58 & 15.8 & 56 & 30.1 & $<0.001$ \\
\hline $1-6$ & 107 & 29.2 & 54 & 20.9 & \\
\hline $7-12$ & 157 & 42.9 & 55 & 29.6 & \\
\hline $12+$ & 44 & 12.0 & 21 & 11.3 & \\
\hline
\end{tabular}

$\mathrm{n}=$ total number of respondents: data were missing for some categories.

noted in the age distribution, marital status, level of education and occupation.

\section{TB presentation and health- seeking behaviour}

Table 2 shows no significant differences in the clinical presentation of the disease among males and females. The median period between onset of symptoms and reporting to the health facility was 30 days (range 2-1800). The mean number of days of delay was significantly longer for males than females (63.6 days versus 40.0 days, respectively). Significant differences be- tween males and females were noted in relation to the first place they usually go to seek care (Table 2); a higher proportion of males sought care at public hospitals, and a higher proportion of females sought care from private physicians. It should be noted that $3.1 \%$ of study subjects sought care from pharmacies. The period between onset of symptoms and reporting to the health facility was longest for those who sought care from hospitals (mean 71.0 days).

Patients were questioned about their knowledge of TB. Table 3 shows that sex did not seem to be related to knowledge of 


\begin{tabular}{|c|c|c|c|c|c|}
\hline \multirow[t]{2}{*}{ Variable } & \multicolumn{2}{|c|}{ Males $(n=366)$} & \multicolumn{2}{|c|}{ Females $(n=186)$} & \multirow[t]{2}{*}{$P$-value } \\
\hline & & $\%$ & & & \\
\hline \multicolumn{6}{|l|}{ Clinical presentation } \\
\hline Cough & 352 & 96.2 & 183 & 98.4 & 0.120 \\
\hline Fever & 247 & 67.5 & 136 & 73.1 & 0.103 \\
\hline Loss of appetite & 255 & 69.7 & 140 & 75.3 & 0.100 \\
\hline Loss of weight & 270 & 73.8 & 144 & 77.4 & 0.203 \\
\hline Blood in sputum & 209 & 57.1 & 108 & 58.1 & 0.451 \\
\hline \multicolumn{6}{|l|}{ Place of first visit } \\
\hline Hospital & 71 & 19.6 & 14 & 7.6 & 0.005 \\
\hline Private physician & 241 & 66.4 & 149 & 81.0 & \\
\hline Health centre ${ }^{a}$ & 32 & 8.8 & 15 & 8.2 & \\
\hline Pharmacy & 13 & 3.6 & 4 & 2.2 & \\
\hline Other & 6 & 1.7 & 2 & 1.1 & \\
\hline \multicolumn{6}{|l|}{$\begin{array}{l}\text { Delay in seeking care } \\
\text { (days) }\end{array}$} \\
\hline$\leq 30$ & 220 & 63.6 & 116 & 67.8 & 0.41 \\
\hline $31-90$ & 66 & 19.1 & 33 & 19.3 & \\
\hline$>90$ & 60 & 17.3 & 22 & 12.9 & \\
\hline
\end{tabular}

alncludes TB centres.

$\mathrm{n}=$ total number of respondents: data were missing for some categories.

TB patients, even after developing a summation score for knowledge (mean knowledge score for males was 2.8 and for females 2.7, $P>0.05$ ).

Table 3 also shows that male and female subjects had significant differences in their gender attitudes and perceptions of careseeking behaviour. Sixty-six out of 70 patients, 41 males, thought that women are inferior to men. Due to the large number of the missing values for this item, the characteristics of respondents and non-respondents' were compared and showed that the non-respondents were from the younger age groups. A large proportion of women (71.3\%) reported that they need permission to go to the TB centre and had to be accompanied by someone (86.8\%). Overall, the mean gender perception score of males was significantly higher than females (5.0 \pm 0.9 versus $3.7 \pm 1.2)(P<0.001)$.

Most patients were satisfied with the service provided at the health centre ( $99.7 \%$ of men versus $97.8 \%$ of women) $(P>0.05)$. Slightly more men than women (93.6\% versus $87.4 \%$ ) thought that the visit to the TB clinic was convenient $(P>$ 0.05 ). However, some of them experienced long waiting times: $12.4 \%$ of females and $10.9 \%$ of males $(P>0.05)$. The mean score for satisfaction with care was higher among men than women $(2.8 \pm 0.4$ versus $2.7 \pm 0.5)(P=0.02)$.

\section{Treatment outcome and its determinants}

Table 4 summarizes the differences between females and males in compliance

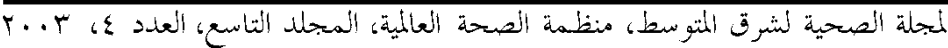




\begin{tabular}{|c|c|c|c|c|c|}
\hline \multirow[t]{2}{*}{ Item } & \multicolumn{2}{|c|}{ Males $(n=366)$} & \multicolumn{2}{|c|}{ Females $(n=186)$} & \multirow[t]{2}{*}{$P$-value } \\
\hline & No. & $\%$ & No. & $\%$ & \\
\hline \multicolumn{6}{|l|}{ Knowledge } \\
\hline Knows TB is a transmissible disease & 278 & 77.0 & 139 & 79.0 & 0.607 \\
\hline Knows correct mode of transmission & 162 & 48.1 & 77 & 46.7 & 0.767 \\
\hline Agrees TB is a stigmatized disease & 124 & 37.3 & 65 & 39.9 & 0.586 \\
\hline Agrees stigma differs by sex & 28 & 9.0 & 21 & 13.2 & 0.20 \\
\hline Mean $\pm s$ knowledge score $(\max .=4)$ & \multicolumn{2}{|c|}{$2.8 \pm 0.9$} & \multicolumn{2}{|c|}{$2.7 \pm 0.9$} & 0.35 \\
\hline \multicolumn{6}{|l|}{ Gender perceptions } \\
\hline $\begin{array}{l}\text { Believes one sex is inferior to another } \\
\text { Believes being a man/woman prevents }\end{array}$ & 46 & 19.7 & 28 & 24.3 & 0.323 \\
\hline them from discussing health problems & 22 & 6.0 & 33 & 18.1 & $<0.001$ \\
\hline $\begin{array}{l}\text { Believes being a man/woman prevents } \\
\text { them from seeking care }\end{array}$ & 9 & 2.5 & 17 & 9.3 & $<0.001$ \\
\hline $\begin{array}{l}\text { Believes being a man/woman prevents } \\
\text { them from getting treatment }\end{array}$ & 12 & 3.3 & 12 & 6.6 & 0.076 \\
\hline $\begin{array}{l}\text { Agrees being a man/woman they need } \\
\text { permission to go to the health centre } \\
\text { Agrees being a man/woman they need }\end{array}$ & 99 & 28.5 & 127 & 71.3 & $<0.001$ \\
\hline companion to go to the health centre & 103 & 29.3 & 158 & 86.8 & $<0.001$ \\
\hline \multicolumn{5}{|l|}{ Mean $\pm s$ gender perception score } & $<0.001$ \\
\hline
\end{tabular}

$\mathrm{n}=$ total number of respondents: data were missing for some categories.

$s=$ standard deviation.

with treatment and treatment outcomes. Treatment cards of only 528 patients were analysed. The results did not show any sex differences in the adherence rate to the schedule of sputum submission for treatment supervision. The conversion rate to smear negative after 2 months of treatment was $78.6 \%$ among males and $77.2 \%$ among females $(P=0.804)$. Compliance with drug treatment did not significantly differ between males and females. The mean number days of treatment missed during the 2-month initial phase of treatment was $10.4 \pm 11.3$ among males and 9.3 \pm 8.8 among females. The mean number of days of missed treatment during the 4month continuation phase of treatment was
$39.2 \pm 40.8$ for males versus $26.8 \pm 34.7$ for females. The defaulter rate was higher among males than females ( $8.7 \%$ versus $5.8 \%$ respectively), but overall there were no significant differences in the distribution of treatment outcomes between males and females (Table 4).

The treatment success rate (that is cure and completion of treatment) was higher among females than males, with no significant difference $(90.1 \%$ for females versus $85.6 \%$ for males). As can be seen from Tables 5 and 6, the success rate was significantly higher among the younger and more literate patients, those who did not report a delay in seeking care after experiencing symptoms, those who adhered with the 


\begin{tabular}{|c|c|c|c|c|c|c|c|}
\hline \multicolumn{7}{|c|}{ Eastern Mediterranean Health Journal, Vol. 9, No. 4, 2003} & \\
\hline \multicolumn{7}{|c|}{ Table 4 Treatment compliance and outcomes among tuberculosis patients according to sex } & \\
\hline \multirow[t]{2}{*}{ Item } & \multicolumn{2}{|c|}{ Males $(n=366)$} & \multicolumn{2}{|c|}{ Females $(n=186)$} & \multicolumn{2}{|c|}{ Total } & \multirow[t]{2}{*}{$P$-value } \\
\hline & No. & $\%$ & No. & $\%$ & No. & $\%$ & \\
\hline \multicolumn{8}{|l|}{ Compliance } \\
\hline $\begin{array}{l}\text { Compliant with sputum } \\
\text { examination }\end{array}$ & 224 & 63.6 & 118 & 68.2 & 342 & 65.1 & 0.349 \\
\hline $\begin{array}{l}\text { Compliant with treatment, } \\
\text { initial phase }^{\mathrm{a}}\end{array}$ & 292 & 83.7 & 137 & 82.0 & 429 & 83.1 & 0.736 \\
\hline $\begin{array}{l}\text { Compliant with treatment, } \\
\text { continuation phase } \mathrm{e}^{\mathrm{a}}\end{array}$ & 235 & 70.6 & 114 & 69.1 & 349 & 70.1 & 0.814 \\
\hline \multicolumn{8}{|l|}{ Conversion to smear negative } \\
\hline $\begin{array}{l}\text { treatment } \\
\text { Conversion rate after } 3 \text { months }\end{array}$ & 250 & 78.6 & 125 & 77.2 & 375 & 78.1 & 0.804 \\
\hline treatment ${ }^{\mathrm{b}}$ & 36 & 52.2 & 24 & 66.7 & 60 & 57.1 & 0.224 \\
\hline \multicolumn{8}{|l|}{ Outcome $^{\mathrm{c}}$} \\
\hline Cure & 238 & 67.0 & 122 & 70.5 & 360 & 68.2 & 0.254 \\
\hline Treatment completed & 53 & 14.9 & 32 & 18.5 & 85 & 16.1 & \\
\hline Treatment failure & 13 & 3.7 & 4 & 2.3 & 17 & 3.2 & \\
\hline Default & 31 & 8.7 & 10 & 5.8 & 41 & 7.8 & \\
\hline Transfer out & 15 & 4.2 & 2 & 1.2 & 17 & 3.2 & \\
\hline Death & 5 & 1.4 & 3 & 1.7 & 8 & 1.5 & \\
\hline
\end{tabular}

${ }^{a} 0$ days of missed treatment.

bPatients who did not convert after 2 months.

'WHO definitions [11].

$\mathrm{n}=$ total number of respondents: data were missing for some categories.

schedule of the sputum examination and those who complied well with treatment.

Univariate analysis showed that the significant risk factors for a negative treatment outcome (that is default, failure or death) were: illiteracy (2.4-fold increased risk); delay $\geq 3$ months in seeking care (2.4-fold increased risk); non-adherence to sputum examination (12.7-fold increased risk); and non-compliance during the initial or maintenance phases of treatment (4.0 and 13.9-fold increased risk respectively) (Table 7). The attributable fraction among those who did not adhere to the schedule of sputum examination was $92.1 \%$; that is the proportion by which the risk of a negative treatment outcome would be reduced if non-adherence was eliminated. Similarly, the attributable fraction for non-compliance with treatment was very high as well (75.1\% for the initial phase and $92.8 \%$ for the maintenance phase).

Multivariate analysis (Table 8) showed that, after adjustment for confounders, the significant risk factors for a negative treatment outcome were: male sex (2.9-fold increased risk), illiteracy (4.1-fold increased risk), non-adherence to sputum examination (9.8-fold increased risk) and non-compliance with treatment during the initial or maintenance phases (adjusted RR of 2.6 and 10.8 respectively). Three months or more delay in seeking care was associated with an increased risk of a negative treat-

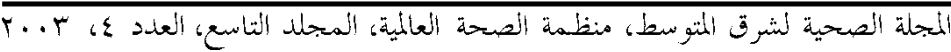




\begin{tabular}{|c|c|c|c|c|c|}
\hline \multirow{2}{*}{\multicolumn{3}{|c|}{$\begin{array}{l}\text { Table } 5 \text { Sociodemographic } \\
\text { treatment success (cured } \\
\text { treatment) among tubercu } \\
\text { Variable } \\
\begin{array}{ll}\text { Success } \\
(n=445) \\
\text { No. } \%\end{array}\end{array}$}} & \multicolumn{2}{|c|}{$\begin{array}{l}\text { Failure } \\
(n=66)\end{array}$} & \multirow[t]{2}{*}{$P$-value } \\
\hline & & & No. & $\%$ & \\
\hline \multicolumn{6}{|l|}{ Age (years) } \\
\hline$<40$ & 346 & 89.4 & 41 & 10.6 & 0.009 \\
\hline $40+$ & 99 & 79.8 & 25 & 20.2 & \\
\hline \multicolumn{6}{|l|}{ Sex } \\
\hline Male & 291 & 85.6 & 49 & 14.4 & 0.098 \\
\hline Female & 154 & 90.1 & 17 & 9.9 & \\
\hline \multicolumn{6}{|l|}{ Marital status } \\
\hline Single & 215 & 90.3 & 23 & 9.7 & 0.130 \\
\hline Married & 214 & 84.3 & 40 & 15.7 & \\
\hline Other & 15 & 88.2 & 2 & 11.8 & \\
\hline \multicolumn{6}{|l|}{ Occupation } \\
\hline Unemployed & 134 & 88.2 & 18 & 11.8 & 0.570 \\
\hline Labourer & 85 & 84.2 & 16 & 15.8 & \\
\hline Agriculture & 48 & 84.2 & 9 & 15.8 & \\
\hline Military & 28 & 93.3 & 2 & 6.7 & \\
\hline Small industry & 69 & 89.6 & 8 & 10.4 & \\
\hline Clerk & 28 & 80.0 & 7 & 20.0 & \\
\hline Others & 22 & 91.7 & 2 & 8.3 & \\
\hline \multicolumn{6}{|l|}{ Education } \\
\hline Literate & 366 & 89.9 & 41 & 10.1 & 0.002 \\
\hline Illiterate & 79 & 76.0 & 25 & 24.0 & \\
\hline \multicolumn{6}{|l|}{$\begin{array}{l}\text { House owner- } \\
\text { ship }\end{array}$} \\
\hline Yes & 344 & 88.7 & 44 & 11.3 & 0.060 \\
\hline No & 85 & 81.7 & 19 & 18.3 & \\
\hline
\end{tabular}

$\mathrm{n}=$ total number of respondents.

ment outcome in the bivariate analysis; however, after adjusting for confounders by the multivariate analysis, this proved to have no significant effect in our study.

\section{Discussion}

This study hypothesized that sex is a determinant of the diagnosis, compliance and treatment of TB. Our results showed some important gender differentials. To fit our results into the conceptual framework suggested by WHO [1], we will discuss them according to different potential barriers related to gender.

The presentation of symptoms did not differ between males and females. However, symptomatic males took a significantly longer time on average to seek medical care. Due to the delay, it is likely that more severe cases occurred among males and it is therefore not surprising that more males sought care at hospitals.

The summation score for patients' knowledge did not differ between males and females. Males, however, reported better overall scores in terms of gender perceptions; that is, they experienced culturally more favourable circumstances for seeking care when needed. Males were also more satisfied with their care, while women tended to report longer waiting time at TB centres. We cannot assume that this was a result of gender bias by care providers at TB clinics; the finding could also be explained by women's perceptions of time and the time pressure on them at leaving the house and the children. Stigma did not seem to prevent women from seeking care. In this study, however, we were not able to identify any gender bias in the TB service for two reasons: first, we did not study this question due to its sensitive nature, and secondly, because the TB service is only provided by the TB health facilities under the Syrian National TB Programme.

Compliance with treatment and treatment supervision schedules did not significantly differ between males and females, in spite of the much higher proportion of women who need to get permission to go to the health centre and who need to have a companion with them. This study confirmed that women are generally more likely to comply with $\mathrm{TB}$ treatment than men,

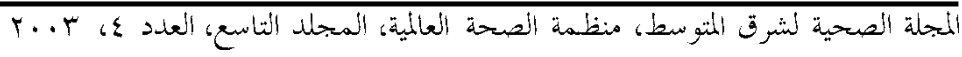


Table 6 Health care related determinants of treatment success (cured and completed treatment) among tuberculosis patients

\begin{tabular}{|c|c|c|c|c|c|}
\hline \multirow[t]{2}{*}{ Variable } & \multicolumn{2}{|c|}{ Success $(n=445)$} & \multicolumn{2}{|c|}{ Failure $(n=66)$} & \multirow[t]{2}{*}{$P$-value } \\
\hline & No. & $\%$ & No. & $\%$ & \\
\hline \multicolumn{6}{|l|}{ Place of first visit } \\
\hline Hospital & 68 & 84.0 & 13 & 16.0 & 0.08 \\
\hline Private physician & 322 & 89.2 & 39 & 10.8 & \\
\hline Health centre & 33 & 76.7 & 10 & 23.3 & \\
\hline Pharmacy & 11 & 78.6 & 3 & 21.4 & \\
\hline Other & 8 & 100.0 & 0 & 0 & \\
\hline \multicolumn{6}{|l|}{ Delay in seeking care (days) } \\
\hline$\leq 30$ & 281 & 90.4 & 30 & 9.6 & $0.003^{b}$ \\
\hline $31-90$ & 81 & 87.1 & 12 & 12.9 & \\
\hline$>90$ & 57 & 77.0 & 17 & 23.0 & \\
\hline \multicolumn{6}{|l|}{ Compliant with sputum examination } \\
\hline Yes & 332 & 97.4 & 9 & 2.6 & $<0.001$ \\
\hline No & 113 & 66.5 & 57 & 33.5 & \\
\hline Other variables & \multicolumn{4}{|c|}{ Mean $\pm s$} & \\
\hline Missed treatment, initial phase (days) & \multicolumn{2}{|c|}{$0.8 \pm 3.14$} & \multicolumn{2}{|c|}{$6.9 \pm 12.3$} & $<0.001$ \\
\hline $\begin{array}{l}\text { Missed treatment, continuation phase } \\
\text { (days) }\end{array}$ & \multicolumn{2}{|c|}{$3.2 \pm 9.5$} & \multicolumn{2}{|c|}{$68.1 \pm 44.9$} & $<0.001$ \\
\hline Knowledge score & \multicolumn{2}{|c|}{$2.8 \pm 0.9$} & \multicolumn{2}{|c|}{$2.8 \pm 0.8$} & 0.70 \\
\hline Gender perception score & \multicolumn{2}{|c|}{$5.0 \pm 0.9$} & \multicolumn{2}{|c|}{$3.7 \pm 1.2$} & 0.60 \\
\hline Satisfaction score & \multicolumn{2}{|c|}{$2.8 \pm 0.4$} & \multicolumn{2}{|c|}{$2.7 \pm 0.5$} & 0.06 \\
\hline Travel time to health facility (min) & \multicolumn{2}{|c|}{$38.7 \pm 33.5$} & \multicolumn{2}{|c|}{$42.9 \pm 39.7$} & 0.34 \\
\hline Travel cost (SP) & \multicolumn{2}{|c|}{$39.1 \pm 50.7$} & \multicolumn{2}{|c|}{$51.8 \pm 67.7$} & 0.14 \\
\hline Waiting time (min) & \multicolumn{2}{|c|}{$18.5 \pm 29.9$} & \multicolumn{2}{|c|}{$35.8 \pm 54.1$} & 0.15 \\
\hline
\end{tabular}

${ }^{a} \chi^{2}$-tests for categorical variables and t-test for continuous variables.

${ }^{\mathrm{D} P}$-value from $\chi^{2}$ for trend.

$\mathrm{n}=$ total number of respondents.

$s=$ standard deviation.

$S P=$ Syrian pounds.

despite the fact that they are more affected by cultural and environmental factors that may work against them $[1,9]$.

Multivariate analysis revealed that male sex was a significant predictor of a negative treatment outcome after adjusting for confounders. The only social factor that determined a negative TB treatment outcome was illiteracy. Other determinants included adherence to sputum examination and adherence to treatment, either in the initial phase or the continuation phase.

This study has identified barriers related to the utilization patterns of TB health services in Syria in the context of culture and sensitivity to gender issues. Fortunately, those barriers did not correlate with TB treatment outcomes, as women in fact had higher success rates. We can argue that stigma, lack of knowledge and perception

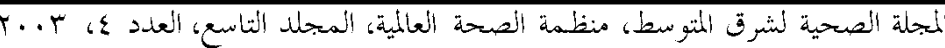




\begin{tabular}{|c|c|c|c|c|c|}
\hline Variable & $\begin{array}{l}\text { Risk } \\
(\%)\end{array}$ & $\begin{array}{l}\text { Crude } \\
\text { RR }\end{array}$ & $95 \% \mathrm{Cl}$ & $\begin{array}{l}\text { Attribut- } \\
\text { able } \\
\text { fraction } \\
(\%)\end{array}$ & $95 \% \mathrm{Cl}^{\mathrm{a}}$ \\
\hline \multicolumn{6}{|c|}{ Age (years) } \\
\hline$<20$ & 12.2 & 1 & & & \\
\hline 20-29 & 9.2 & 0.75 & 0.4 to 1.6 & $24.6^{a}$ & -57.3 to 63.9 \\
\hline 30-39 & 13.1 & 1.10 & 0.5 to 2.5 & $7.1^{\mathrm{a}}$ & -111.6 to 59.2 \\
\hline $40+$ & 20.2 & 1.70 & 0.8 to 3.4 & $39.7^{a}$ & -22.1 to 70.2 \\
\hline \multicolumn{6}{|l|}{ Sex } \\
\hline Female & 9.9 & 1 & & & \\
\hline Male & 14.4 & 1.45 & 0.9 to 2.4 & $31.0^{\mathrm{a}}$ & -16.1 to 59.0 \\
\hline \multicolumn{6}{|l|}{ Education } \\
\hline Literate & 10.1 & 1 & & & \\
\hline Illiterate & 24.0 & 2.40 & 1.5 to 3.7 & 58.1 & 34.4 to 73.2 \\
\hline \multicolumn{6}{|c|}{ Delay in seeking care (days) } \\
\hline$\leq 30$ & 9.7 & 1 & & & \\
\hline $31-90$ & 12.9 & 1.34 & 0.7 to 2.5 & 25.2 & -40.1 to 60.1 \\
\hline$>90$ & 23.0 & 2.40 & 1.4 to 4.1 & 58.0 & 28.1 to 75.5 \\
\hline \multicolumn{6}{|c|}{$\begin{array}{l}\text { Compliant with sputum } \\
\text { examination }\end{array}$} \\
\hline Yes & 2.6 & 1 & & & \\
\hline No & 33.5 & 12.70 & 6.5 to 25.0 & 92.1 & 84.5 to 96.0 \\
\hline \multicolumn{6}{|c|}{$\begin{array}{l}\text { Compliant with treatment, } \\
\text { initial phase }\end{array}$} \\
\hline Yes & 8.5 & 1 & & & \\
\hline No & 34.2 & 4.00 & 2.6 to 6.2 & 75.1 & 61.6 to 83.9 \\
\hline \multicolumn{6}{|c|}{$\begin{array}{l}\text { Compliant with treatment, } \\
\text { continuation phase }\end{array}$} \\
\hline Yes & 2.3 & 1 & & & \\
\hline No & 31.8 & 13.9 & 6.7 to 28.6 & 92.8 & 85.1 to 96.5 \\
\hline
\end{tabular}

aThe attributable fraction does not implicate the 'prevented fraction' in the context of age and sex.

of the gender role in connection with careseeking behaviour did not adversely affect women's care-seeking behaviour, presumably due to the seriousness of TB and due to education activities about the curability of the disease.
Using a quantitative approach for data collection on gender issues in this study may well limit the results. An in-depth qualitative approach might have shown more interesting results. Another limitation of 
Table 8 Multivariate analysis of determinants of a negative treatment outcome among study subjects

\begin{tabular}{|c|c|c|}
\hline Determinant & $\begin{array}{l}\text { Adjusted } \\
\text { RR }\end{array}$ & $95 \% \mathrm{Cl}$ \\
\hline Age & 0.99 & 0.96 to 1.0 \\
\hline \multicolumn{3}{|l|}{ Sex } \\
\hline Female $^{\mathrm{a}}$ & 1 & \\
\hline Male & 2.9 & 1.1 to 7.7 \\
\hline \multicolumn{3}{|l|}{ Education } \\
\hline Literate $^{\mathrm{a}}$ & 1 & \\
\hline Illiterate & 4.1 & 1.6 to 10.9 \\
\hline \multicolumn{3}{|c|}{$\begin{array}{l}\text { Delay in seeking care } \\
\text { (days) }\end{array}$} \\
\hline$\leq 30^{\mathrm{a}}$ & 1 & \\
\hline $31-90$ & 1.7 & 0.6 to 4.8 \\
\hline$>90$ & 2.4 & 0.9 to 6.7 \\
\hline \multicolumn{3}{|c|}{$\begin{array}{l}\text { Compliant with sputum } \\
\text { examination }\end{array}$} \\
\hline$Y_{e s}^{a}$ & 1 & \\
\hline No & 9.8 & 3.9 to 24.8 \\
\hline \multicolumn{3}{|c|}{$\begin{array}{l}\text { Compliant with treatment, } \\
\text { initial phase }\end{array}$} \\
\hline$Y_{e s}{ }^{a}$ & 1 & \\
\hline No & 2.6 & 1.1 to 6.1 \\
\hline \multicolumn{3}{|c|}{$\begin{array}{l}\text { Compliant with treatment, } \\
\text { continuation phase }\end{array}$} \\
\hline Yes $^{a}$ & 1 & \\
\hline No & 10.8 & 4.1 to 29.0 \\
\hline
\end{tabular}

${ }^{a}$ Reference group.

this study is that the interviewers were health personnel working at the TB centres. This may have led to reporting bias for factors such as satisfaction with care.

Finally, since our results revealed gender differences in TB health care seeking behaviour and treatment outcome, this implies that sensitive interventions should rectify any imbalances or inequalities in connection with TB diagnosis, compliance and treatment. Those interventions need to be designed according to local settings. A gender approach to the TB policy and control programme may lead to improvement in the effectiveness of the Syrian National TB Programme. Further research on gender issues and TB, using qualitative approaches, may be important. The protective role of good implementation of TB treatment guidelines in the National Programme need to be stressed in the light of the study results.

\section{Acknowledgements}

We would like to express our sincere appreciation to his Excellency, the Syrian Minister of Health for kind approval to carry out the study. We thank the Dean of the Faculty of Medicine, University of Damascus, for support. We are grateful to the staff of TDR and STB at the WHO Regional Office (EMRO) who backed this work with interest and support. Special thanks are due to Dr Amal Bassili.

This investigation received technical and financial support from the joint WHO Eastern Mediterranean Region (EMRO), Division of Communicable Diseases (DCD) and the WHO Special Programme for Research and Training in Tropical Diseases (TDR): the EMRO/DCD/TDR Small Grants Scheme for Operational Research in Tropical and Communicable Diseases.

\section{References}

1. Gender and tuberculosis control: toGeneva, World Health Organization, wards a strategy for research and action. 1999 (WHO/CDS/TB/2000.280).

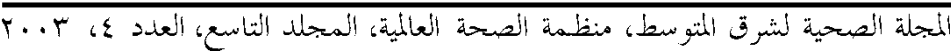


2. Long $\mathrm{NH}$ et al. Longer delays in tuberculosis diagnosis among women in Vietnam. International journal of tuberculosis and lung disease, 1999, 3:388-93.

3. Johansson E et al. Attitudes to compliance with tuberculosis treatment among women and men in Vietnam. International journal of tuberculosis and lung disease, 1999, 3:862-8.

4. Boeree MJ et al. Gender differences in relation to sputum submission and smear-positive pulmonary tuberculosis in Malawi. International journal of tuberculosis and lung disease, 2000, 4:8824.

5. Johansson E et al. Gender and Tuberculosis control, perspectives on health seeking behaviour among men and women in Vietnam. Health policy, 2000, 52:33-51.

6. Borgdroff MW et al. Gender and tuberculosis: a comparison of prevalence surveys with notification data to explore sex differences in case detection. International journal of tuberculosis and lung disease, 2000, 4:123-32.

7. Long $\mathrm{NH}$ et al. Different tuberculosis in men and women: beliefs from focus groups in Vietnam. Social science and medicine, 1999, 49:815-22.

8. Diwan VK and Thorson A. Sex, gender and tuberculosis. Lancet, 1999, 353: 1000-1.

9. Begum $\mathrm{V}$ et al. Tuberculosis and patient gender in Bangladesh: sex differences in diagnosis and treatment outcome. International journal of tuberculosis and lung disease, 2001, 5:604-10.

10. Global tuberculosis control. WHO report 2001. Geneva, World Health Organization, 2001.

11. National TB Programme statistics, 1997-2002. Damascus, Syrian Ministry of Health, 2003. 